\title{
BRPKM
}

Buletin Riset Psikologi dan Kesehatan Mental

http://e-journal.unair.ac.id/index.php/BRPKM

e-ISSN: 2776-1851

\section{Pengaruh Adversity Quotient dan Konsep Diri terhadap Kecemasan dalam Menghadapi Dunia Kerja Masa Pandemi}

\author{
I DEWA GEDE PUTRA BRATAJAYA \& FENDY SUHARIADI* \\ Fakultas Psikologi Universitas Airlangga
}

\begin{abstract}
ABSTRAK
Penelitian ini bertujuan untuk menguji apakah terdapat pengaruh antara adversity quotient yang terdiri dari control, origin, ownership, reach, endurance, dan konsep diri terhadap kecemasan dalam menghadapi dunia kerja pada fresh graduate yang lulus pada saat pandemi terjadi. Kecemasan dalam menghadapi dunia kerja di ukur menggunakan teori kecemasan Greenberger dan Padesky, Konsep diri menggunakan teori Berzonsky dan Adversity quotient menggunakan teori Stoltz. Subjek dalam penelitian ini adalah fresh graduate yang lulus pada masa pandemi. Metode penelitian menggunakan tipe penelitian kuantitatif dengan alat pengumpulan data menggunakan survey melalui google form. Dalam menganalisis data menggunakan SPSS 25 for windows. Hasil analisis menunjukkan regresi menyebutkan bahwa terdapat 51,7\% pengaruh antara Adversity quotient dan Konsep diri terhadap kecemasan dalam menghadapi dunia kerja.
\end{abstract}

Kata kunci: adversity quotient, kecemasan, konsep diri

\begin{abstract}
This study aims to test whether there is an influence between the adversity quotient consisting of control, origin, ownership, reach, endurance, and self-concept on anxiety in facing the world of work for fresh graduates who graduate during the pandemic. Anxiety in unemployment who looking for a job is measured using Greenberger and Padesky's anxiety theory, Berzonsky's for measuring self-concept, and Stoltz's for measuring Adversity quotient. The subjects in this study were fresh graduates who graduated during the pandemic. The research method uses quantitative research type with data collection tools using a survey via google form. In analyzing data using SPSS 25 for windows. The results of the regression analysis show that there is $51.7 \%$ influence between Adversity quotient and Selfconcept on anxiety in dealing with the world of work.
\end{abstract}

Keywords: adversity quotient, anxiety, self-concept

Buletin Penelitian Psikologi dan Kesehatan Mental (BRPKM), tahun, Vol. X(no), pp,

*Alamat korespondensi: Fakultas Psikologi Universitas Airlangga, Kampus B Universitas Airlangga Jalan Airlangga 4-6 Surabaya 60286. Surel: fendy.suhariadi@psikologi.unair.ac.id

Naskah ini merupakan naskah dengan akses terbuka dibawah ketentuan the Creative Common Attribution License (CC-BY-4.0) (http://creativecommons.org/licenses/by/4.0), sehingga penggunaan, distribusi, reproduksi dalam media apapun atas artikel ini tidak dibatasi, selama sumber aslinya disitir dengan baik. 


\section{PENDAHULUAN}

Pandemi Penyakit Coronavirus (COVID-19) 2019 telah meningkatkan kecemasan dan depresi. Ini mungkin sebagian karena dampak pandemi terhadap ekonomi dan angkatan kerja. Kekhawatiran tentang pekerjaan, stabilitas, dan keuangan yang disebabkan oleh pandemi Covid-19 memperburuk kecemasan dan depresi seorang individu (Sibley dkk., 2020). Dari perspektif pekerja, pengusaha dan perusahaan independen, dengan pandemi 2020 yang dikenal dengan nama korona, situasinya semakin parah, terlihat dari dampak pandemi Covid-19 terhadap dunia ketenagakerjaan Indonesia. Hal ini disebabkan terganggunya aktivitas bisnis di sebagian besar sektor, gelombang PHK, dan penurunan pendapatan. Covid-19 yang menghambat kegiatan ekonomi secara otomatis akan merugikan pelaku usaha yang berujung pada PHK atau bahkan PHK banyak pekerja. Menurut data Kementerian Ketenagakerjaan (Kemnaker) per 7 April 2020, 39.977 perusahaan di sektor formal telah melakukan PHK dan PHK karyawan akibat pandemi Covid-19. Jumlah pekerja yang terkena dampak ini adalah 1.010.579 (Statistik, 2020).

Namun, fakta menunjukkan bahwa lulusan perguruan tinggi sulit mendapatkan pekerjaan. Hal ini terlihat dari banyaknya lulusan perguruan tinggi yang masih menganggur. Menurut data diatas, pada Februari 2019, jumlah tersebut masih terbatas pada pekerja dengan tamatan SD ke bawah yaitu 40,51\%. Meski turun sekitar 1\% dari 42,23\% pada 2017, angka ini tidak berubah dalam tiga tahun terakhir. Pada gambar di atas, sarjana atau sarjana baru pada tahun 2019 hanya menyumbang 2,8\% dari pekerjaan, turun dari 0,13\% pada tahun 2017, yang berarti sangat sedikit sarjana yang bekerja dari tahun ke tahun. (Statistik, 2020).

Setelah menyelesaikan studi di perguruan tinggi dan universitas, tantangan yang dihadapi oleh fresh graduate di dunia kerja akan menimbulkan emosi negatif, salah satunya adalah kecemasan. Selain itu, masyarakat yang sedang mencari pekerjaan merasa bahwa proses mencari pekerjaan dianggap sulit dan berkaitan dengan emosi negatif (Wanberg dkk., 2010). Salah satu emosi negatif yang dirasakan oleh fresh graduate merupakan kecemasan.

Kecemasan dalam menghadapi dunia kerja menjadikan individu memiliki stress yang terkait dengan kesulitan dan perasaan negatif (Ashford dkk., 1989). Selama pandemi, dampak psikologis dari kecemasan menghadapi dunia kerja semakin meningkat. Seperti yang terlihat dari kasus pandemi sebelumnya, kasus pandemi juga menunjukkan gejala kecemasan yang berhubungan dengan depresi, seperti wabah SARS. Selama wabah ini, gejala depresi dan tekanan emosional meningkat dari sebelum wabah hingga setelah wabah, dan banyak orang kehilangan pekerjaan, sehingga menambah beban kerja dan tekanan emosional (Liu \& Lu, 2011). Selanjutnya dalam penelitian (Li dkk., 2005). Penurunan pendapatan selama wabah SARS merupakan prediktor terbesar dari perkembangan gangguan psikologis. Ketidakstabilan pekerjaan akibat pandemi COVID-19 bisa dibandingkan dengan pandemi sebelumnya. Karena ketidakpastian lingkungan kerja di bawah pandemi ini, kecemasan terhadap lingkungan kerja akan semakin besar, yang terkait dengan memburuknya kesehatan mental individu (Mihashi dkk., 2009).

Apabila fresh graduate dapat mengatasi kecemasan, mereka akan mampu menghadapi tantangan di tempat kerja. Lulusan baru yang mampu mengatasi kecemasan akan tantangan dunia kerja dapat menganggap dirinya kompeten, mampu menghadapi segala kesulitan atau tantangan, dan mampu mengendalikan ketegangan fisik. Kemampuan mengatasi Kesulitan yang menjadi sumber kecemasan

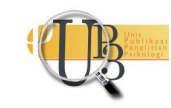


fresh graduate ini dalam kajian psikologi dikenal dengan istilah adversity quotient (Rachmady \& Aprilia, 2018). Stoltz (2000) mencontohkan Adversity Quotient (AQ) adalah kemampuan menghadapi kesulitan. Adversity quotient diyakini dapat mempengaruhi kecemasan fresh graduate karena dapat mengurangi pemikiran negatif dari fresh graduate, seperti berpikir lemah dalam menghadapi tantangan atau tantangan, dan memikirkan hal-hal buruk yang akan terjadi di masa depan. Stolz (2000) Dikemukakan bahwa melalui AQ dapat diketahui berapa lama seseorang mampu bertahan dari kesulitan menghadapi tantangan. Individu yang membuat kemajuan terus menerus dan berkembang sepanjang hidup mereka akan mencapai kesuksesan meskipun berbagai kesulitan dan hambatan.

Penelitian Hanifa (2017) Hal tersebut menunjukkan bahwa AQ memiliki pengaruh yang besar terhadap kecemasan saat menghadapi dunia kerja. Individu dengan AQ tinggi berpendapat bahwa mencari pekerjaan tidak mudah sekarang, tetapi hal ini tidak menjadi masalah, karena individu tersebut ingin terus berjuang dan berharap untuk terus belajar untuk meningkatkan kemampuannya. Orang dengan IQ rendah memperkirakan akan sulit beradaptasi dengan lingkungan kerja, misalnya tidak mudah beradaptasi dengan pekerjaan di tempat kerja, berinteraksi dengan orang baru, mempelajari aturan baru, dan mempelajari pekerjaan baru.

Selain adversity quotient, faktor lain yang mempengaruhi kecemasan dalam menghadapi dunia kerja adalah konsep diri karena menurut Nevid dkk. (2005) adalah faktor kognitif, yang mana didalamnya ada konsep diri. Penelitian yang dilakukan oleh Aryanti (1996) Hal tersebut menunjukkan bahwa partisipan dalam penelitianya memiliki konsep diri yang tinggi, dan memiliki rasa cemas yang sedang ketika berhadapan dengan dunia kerja. Hal ini dikarenakan Orang yang memiliki konsep diri yang tinggi cenderung memiliki kepercayaan diri yang tinggi, penerimaan diri yang tinggi, dan mengetahui kapasitas diri. Hal ini menyebabkan orang tidak mudah cemas dalam mengahadapi suatu masalah. Penelitian tersebut juga melakukan wawancara terhadap 14 partisipan yang mengatakan bahwa dirinya merasa takut jika nantinya akan kalah bersaing dengan lulusan lain, yang disebabkan karna memandang dirinya tidak mampu bersaing atau mempunyai konsep diri yang rendah.

Hal ini, dikuatkan oleh Nevid, dkk (2005) yang mengatakan perlunya konsep diri fresh graduate berfungsi untuk mengubah kecemasan menjadi kepercayaan diri, sehingga mengubah kecemasan menjadi kepercayaan diri untuk menghadapi kesulitan yang ada. Orang yang percaya diri dianggap lebih mungkin menghadapi dunia kerja saat ini karena memiliki rasa percaya diri, sikap yang baik dan keberanian menghadapi tantangan di dunia kerja, sehingga konsep diri dalam diri individu memiliki hubungan dengan kecemasan dalam menghadapi dunia kerja (Gufron \& Risnawati, 2014). Berdasarkan uraian diatas penulis tertarik untuk melakukan penelitian tentang pengaruh adversity quotient dan konsep diri terhadap kecemasan dalam menghadapi dunia kerja pada fresh graduate Universitas Airlangga.

\section{Desain Penelitian}

\section{METODE}

Pendekatan yang digunakan dalam penelitian ini menggunakan pendekatan kuantitatif. Penelitian kuantitatif merupakan penelitian yang menggunakan pendekatan positivisme dan memiliki asumsi bahwa suatu realitas sosial dibentuk dari adanya fakta objektif yang diperoleh dari uji statistik untuk mengetahui adanya pengaruh antar variabel (Neuman, 2007). Penelitian ini menggunakan metode survey karena metode ini dapat memberikan gambaran kepada peneliti tentang bagaimana seseorang 
berpikir dan berlaku sesuai dengan pernyataan pada kuesioner (Neuman, 2007). Metode penelitian yang akan digunakan penulis untuk penelitian ini adalah metode penelitian kuantitatif eksplanatori.

Partisipan

Partisipan dalam penelitian ini adalah karyawan dalam suatu perusahaan atau instansi di Indonesia yang termasuk dalam kategori karyawan yang sedang terdampak pandemi covid-19 dan memiliki atasan. Setelah melakukan proses pengumpulan data berdasarkan kriteria, maka diperoleh partisipan sejumlah 66 orang. Pengumpulan data dilakukan dalam jaringan (daring) secara sukarela melalui google form.

Partisipan dalam penelitian ini akan menggunakan non probability sampling teknik ini digunakan jika tidak memiliki data atau pengetahuan tentang seberapa besar populasi yang harus diteliti. Peneliti menggunakan teknik dari Pallant (2013) karena tidak mengetahui atau memiliki data populasi yang harus diteliti dan dipilih karena menghadapi keterbatasan dana dan waktu penelitian.

\section{Teknik Pengumpulan Data}

Untuk menguji hipotesis penelitian penulis menyebar data dan memperoleh 71 partisipan, 23 partisipan yang memiliki jenis kelamin laki-laki dengan presentase 32,4\% dan sebanyak 48 partisipan yang memiliki jenis kelamin perempuan dengan presentase 67,6\%. Rentang usia dari 20 hingga 25 tahun yang didominasi oleh responden diumur 23 tahun yaitu 26 orang atau 36,6\% sedangkan yang terkecil ada direntang usia 25 tahun yaitu hanya 2 responden atau 2,8\%.

\section{Pengukuran}

\section{Kecemasan dalam Menghadapi Dunia Kerja (Y)}

Kecemasan dalam dunia kerja merupakan respon seseorang terhadap kondisi yang membuat seseorang merasa cemas. Saat menghadapi dunia kerja, respons kecemasan tidak hanya pada tubuh, pikiran, perilaku, dan respons emosional. Data kecemasan menghadapi dunia kerja diperoleh dari skala kecemasan menghadapi dunia kerja yang melibatkan aspek kecemasan (Greenberger \& Padesky, 1995). alat ukur ini memiliki koefisien reliabilitas yang cukup baik $(\alpha=.754)$.

\section{Adversity Quotient}

Skala AQ yang digunakan dalam penelitian ini menggunakan konstruk AQ yang diciptakan oleh Stolz (2000) AQ terdiri dari 4 dimensi yaitu: Control, Origin \& Ownership, Reach, dan Endurance. Alat ukur ini memiliki koefisien reliabilitas yang cukup baik dimensi Control $(\alpha=.703)$, Origin $(\alpha=.621)$, Ownership $(\alpha=.659)$, Reach $(\alpha=.613)$, dan Endurance ( $\alpha=.615)$.

\section{Konsep Diri}

Konsep diri menurut Berzonsky (1981) merupakan pandangan, pemikiran atau pendapat tentang dirinya dimana pandangan tersebut merupakan hasil interaksi antara dirinya dengan lingkungannya. Konsep diri terdiri dari empat aspek yaitu aspek fisik, aspek psikis, aspek sosial, dan aspek moral. ukur ini memiliki koefisien reliabilitas yang cukup baik $(\alpha=.735)$.

Analisis Data 
Dalam penelitian ini memiliki tujuan untuk menguji pengaruh antar tiga variabel yakni, adversity quotient $\left(\mathrm{X}_{1}\right)$, konsep diri $\left(\mathrm{X}_{2}\right)$, dengan kecemasan dalam menghadapi dunia kerja $(\mathrm{Y})$ dengan menggunakan teknik korelasi pada IBM SPSS Statistic 25.0 version for Windows.

\section{HASIL PENELITIAN}

Subjek dalam penelitian ini adalah fresh graduate yang lulus pada saat pandemi berlangsung. Hasil dari survey yang di lakukan di google form mendapatkan responden sebanyak 71. sebanyak 71 responden dengan masing-masing jumlah yaitu 23 responden yang memiliki jenis kelamin laki-laki dan sebanyak 48 responden yang memiliki jenis kelamin perempuan.

Variable Control mempunyai rata rata sebesar 20.23 dengan angka minimal 14 dan maksimal 26 serta mempunyai standar deviasi sebesar 2,325. Origin mempunyai rerata sebesar 22,23 dengan angka minimal 15 dan maksimal 28 serta mempunyai standar deviasi sebesar 3,072. Ownership mempunyai rerata sebesar 19,92 dengan angka minimal 14 dan maksimal 27 serta mempunyai standar deviasi sebesar 3,079. Reach mempunyai rerata sebesar 19,65 dengan angka minimal 13 dan maksimal 25 serta mempunyai standar deviasi sebesar 2,721. Endurance mempunyai rerata sebesar 18.68 dengan angka minimal 12 dan maksimal 24 serta mempunyai standar deviasi sebesar 2,551. Kecemasan mempunyai rerata sebesar 58.01 dengan angka minimal 40 dan maksimal 73 serta mempunyai standar deviasi sebesar 7,778. Konsep diri mempunyai rerata sebesar 111,92 dengan angka minimal 72 dan maksimal 131 serta mempunyai standar deviasi sebesar 8,540.

Penelitian ini menggunakan uji regresi berganda dilakukan untuk menguji apakah variabel origin, ownership, reach, endurance, dan konsep diri terhadap kecemasan dalam menghadapi dunia kerja. Diperoleh Nilai $\mathrm{R}^{2}$ sebesar 0,517 atau 51,7\%. Hal ini menunjukan bahwa variabel independen, yaitu origin, ownership, reach, endurance, dan konsep diri mempengaruhi variabel dependen yaitu kecemasan dalam menghadapi dunia kerja sebesar $51,7 \%$. dan semua variabel kecuali origin berpengaruh secara signifikan karena mempunyai nilai signifikansi dibawah 0,05 sedangkan variabel origin mempunyai nilai signifikansi diatas 0,05 yaitu 0,415.

\section{DISKUSI}

Penelitian ini bertujuan untuk menguji apakah terdapat pengaruh antara adversity quotient yang terdiri dari control, origin, ownership, reach, endurance, dan konsep diri terhadap kecemasan dalam menghadapi dunia kerja pada fresh graduate yang lulus pada saat pandemi terjadi. Berdasarkan hasil analisis regresi berganda yang dilakukan oleh peneliti terdapat pengaruh yang signifikan antara ownership, reach, endurance, dan konsep diri terhadap kecemasan dalam menghadapi dunia kerja sebanyak 51,7 persen dilihat dari nilai $\mathrm{R}^{2}$ sebesar 0,517. Sedangkan untuk origin dan kecemasan dalam menghadapi dunia kerja tidak mempunyai pengaruh yang signifikan sehingga peneliti hanya dapat melakukan uji regresi sederhana pada ke empat variabel yaitu, ownership, reach, endurance, dan konsep diri terhadap kecemasan dalam menghadapi dunia kerja.

Hasil penelitian yang dilakukan menunjukan bahwa rata-rata responden memiliki kecemasan yang rendah dalam menghadapi dunia kerja yaitu, sebanyak 25 responden atau setara 35,2\%. Namun mahasiswa yang mamiliki kecemasan yang tinggi dalam menghadapi dunia kerja juga tidak sedikit yaitu sebanyak 19 responden atau 26,8\%. Serta peneliti menemukan bahwa responden miliki konsep diri yang rendah. Untuk variabel adversity quotient yaitu control, origin, ownership, dan reach yang dimiliki 
responden didominasi kategori sedang sedangkan endurance yang dimiliki oleh responden ada pada kategori tinggi.

Hussain (dalam Pandey dkk., 2006) mengemukakan bahwa kecemasan dalam menghadapi dunia kerja dapat disebabkan oleh faktor kognitif, faktor emosi dan faktor tuntutan sosial. Faktor kognitif adalah faktor-faktor yang berhubungan dengan persepsi atau pemikiran mahasiswa, antara lain kecemasan menghadapi dunia kerja, seperti ketidakmampuan memecahkan masalah, keseriusan berpikir, dan ketidakmampuan mengatasi kekhawatiran. Faktor emosional merupakan faktor yang berhubungan dengan emosi mahasiswa, diantaranya adalah rasa takut dan gugup yang kuat tentang munculnya situasi yang mengerikan. Faktor tuntutan sosial adalah faktor-faktor yang berhubungan dengan lingkungan, misalnya adanya standar keberhasilan yang terlalu tinggi bagi kemampuan siswa setelah lulus, dan tidak siap menghadapi situasi yang tidak diharapkan atau tidak terduga.

Selain itu penelitian lain yang dilakukan oleh Stoltz (2000) mengatakan seseorang dengan adversity quotient yang tinggi akan menjadikan seseorang yang tekun dalam hidup dan tidak mudah menyerah, kebal terhadap ketidakmampuannya menghadapi masalah, dan tidak mudah jatuh dalam keadaan putus asa, maka dapat disimpulkan bahwa dalam keterpurukan kecerdasan, seorang individu dapat mereduksi faktor-faktor berpikir negatif, seperti melihat diri sendiri tidak mampu menghadapi masalah dan memikirkan hal-hal buruk yang akan terjadi. Tentunya dengan adversity quotient tersebut juga dapat mengurangi faktor reaksi fisik yang diakibatkan individu dalam menghadapi kecemasan di dunia kerja.

Selain adversity quotient, konsep diri memegang peranan yang cukup signifikan dalam mengontrol kecemasan. konsep diri yang dimiliki individu akan memberikan pandangan terhadap diri individu bagimana individu akan melakukan aksi maupun reaksi yang ia terima dari linkungannya. konsep diri akan memberikan solusi maupun cara bagimana individu akan meredam atau menghadapi kecemasannya. Artinya, apabila konsep diri tinggi maka akan mempengaruhi kecemasan individu. Lebih lanjut, konsep diri memainkan peran penting dalam mempengaruhi perilaku dan harapan seseorang (Burn, 1993). Perilaku yang ditampilkan individu akan sejalan dengan cara individu memandang dirinya sendiri. Dapat dikatakan bahwa orang dengan konsep diri yang positif akan menunjukkan perilaku yang positif, dan orang dengan konsep diri yang negatif juga akan menunjukkan perilaku yang negatif. Sepertinya halnya responden penelitian dimana saat mereka mempunyai konsep diri yang tinggi maka kecemasan dalam menghadapi dunia kerja akan rendah.

Faktor-faktor yang mempengaruhi rendahnya tingkat kecemasan dalam menghadapi dunia kerja adalah pengalaman magang/kerja praktek/kerja lapangan aktual yang dilakukan oleh masing-masing dosen, dan informasi yang baik tentang dunia kerja diperoleh dari berbagai media serta orang dari lingkungan kerja. Pernyataan tersebut diperkuat oleh penelitian yang dilakukan oleh Noor Akbar (2013) hasil penelitiannya menunjukkan bahwa informasi tentang dunia kerja dan pengalaman praktik kerja industri secara bersama-sama berdampak positif terhadap persiapan kerja mahasiswa sehingga menjadikan kecemasan menghadapi dunia kerja yang rendah. 


\section{SIMPULAN}

Berdasarkan hasil analisis data, maka dapat disimpulkan bahwa ownership, reach, endurance, dan konsep diri berpengaruh secara signifikan terhadap kecemasan dalam menghadapi dunia kerja. Sedangkan control dan origin tidak memiliki pengaruh yang significant terhadap kecemasan dalam menghadapi dunia kerja dan ditemukan juga bahwa mahasiswa dalam penelitian ini memiliki konsep diri yang rendah.

\section{UCAPAN TERIMAKASIH}

Alhamdulillah, puji syukur kehadirat Tuhan yang maha esa karena atas berkat rahmat dan hidayahnya, penulis diberi kemudahan dan kelancaran dalam menyelesaikan skripsi dengan judul "Pengaruh Adversity Quontient dan Konsep diri Terhadap Kecemasan dalam menghadapi dunia kerja pada Fresh Graduate di Masa Pandemi" sebagai salah satu prasyarat untuk memperoleh gelar Sarjana Psikologi Universitas Airlangga Surabaya. Penulis menyadari bahwa skripsi ini tidak akan selesai tanpa bantuan dan dukungan dari banyak pihak yang turut andil dalam proses pengerjaannya. Oleh karena itu pada kesempatan ini, penulis ingim menyampaikan terima kasih kepada.

\section{DEKLARASI POTENSI TERJADINYA KONFLIK KEPENTINGAN}

I Dewa Gede Putra Bratajaya dan Fendy Suhariadi tidak bekerja, menjadi konsultan, memiliki saham, atau menerima dana dari perusahaan atau organisasi manapun yang mungkin akan mengambil untung dari diterbitkannya naskah ini.

\section{PUSTAKA ACUAN}

Aryanti, N. F. (1996). Perpustakaan Unia 7. 12(1), 99-127.

Ashford, S. J., Lee, C., \& Bobko, P. (1989). Content, Cause, and Consequences of Job Insecurity: A TheoryBased Measure and Substantive Test. Academy of Management Journal, 32(4), 803-829. https://doi.org/10.5465/256569

Berzonsky, M. D. (1981). Adolescent development. Macmillan.

Burn, R. B. (1993). Konsep diri: Teori, Pengukuran dan Perkembangan Perilaku (Eddy (ed.)). Arcan. Jakarta

Greenberger, D., \& Padesky, C. A. (1995). Mind over Mood: a cognitive therapy treatment manual for clients. Guilford press.

Gufron, N., \& Risnawati, R. (2014). PERBEDAAN BUDAYA DALAM KEPERCAYAAN EPISTEMOLOGI PERSONAL. EDUKASIA, 9(2)

Hanifa, Y. (2017). Emotional Quotient dan Adversity Quotient dengan Kecemasan Menghadapi Dunia Kerja. Psikoborneo: Jurnal Ilmiah Psikologi, 5(1), 25-33.

Li, W., Shi, Z., Yu, M., Ren, W., Smith, C., Epstein, J. H., Wang, H., Crameri, G., Hu, Z., Zhang, H., Zhang, J.,

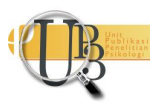


McEachern, J., Field, H., Daszak, P., Eaton, B. T., Zhang, S., \& Wang, L. F. (2005). Bats are natural reservoirs of SARS-like coronaviruses. Science, 310(5748), 676-679. https://doi.org/10.1126/science.1118391

Liu, Y., \& Lu, Z. (2011). The Chinese high school student's stress in the school and academic achievement. Educational Psychology, 31(1), 27-35. https://doi.org/10.1080/01443410.2010.513959

Mihashi, M., Otsubo, Y., Yinjuan, X., Nagatomi, K., Hoshiko, M., \& Ishitake, T. (2009). Predictive Factors of Psychological Disorder Development During Recovery Following SARS Outbreak. Health Psychology, 28(1), 91-100. https://doi.org/10.1037/a0013674

Neuman, W. L. (2014). Basics of social research. Pearson/Allyn and Bacon.

Nevid, J. S., Rathus, S. A., \& Greene, B. (2005). Psikologi abnormal. Jakarta: Erlangga, 96-101

Noor Akbar, S. N. (2013). Hubungan antara kecerdasan emosi dengan stres kerja pada perawat. Jurnal Ecopsy, 1(1). 42-46. https://doi.org/10.20527/ecopsy.v1i1.485

Pallant, J. (2013). SPSS survival manual: A step by step guide to data analysis using. Berkshire, England: McGraw-Hill.

Pandey, M., Sarita, G. P., Devi, N., Thomas, B. C., Hussain, B. M., \& Krishnan, R. (2006). Distress, anxiety, and depression in cancer patients undergoing chemotherapy. World Journal of Surgical Oncology, 4(1), 1-5. https://doi.org/10.1186/1477-7819-4-68

Rachmady, T. N., \& Aprilia, E. D. (2018). Hubungan Adversity Quotient Dengan Kecemasan Menghadapi Dunia Kerja Pada Freshgraduate Universitas Syiah Kuala. Journal Psikogenesis, 6(1), 54-60. https://doi.org/10.24854/jps.v6i1.632

Sibley, C. G., Greaves, L. M., Satherley, N., Wilson, M. S., Overall, N. C., Lee, C. H. J., Milojev, P., Bulbulia, J., Osborne, D., Milfont, T. L., Houkamau, C. A., Duck, I. M., Vickers-Jones, R., \& Barlow, F. K. (2020). Effects of the COVID-19 pandemic and nationwide lockdown on trust, attitudes toward government, and well-being. American Psychologist, 75(5), 618-630. https://doi.org/10.1037/amp0000662

Stoltz, P. G. (2000). Adversity quotient. Jakarta: Grasindo.

Statistik, B. P. (2020). Berita Resmi Statistik Keadaan Ketenagakerjaan Indonesia Februari 2020. Jakarta: Badan Pusat Statistik.

Wanberg, C., Zhu, J., \& Van Hooft, E. A. (2010). The job search grind: Perceived progress, self-reactions, and self-regulation of search effort. Academy of Management Journal, 53(4), 788-807. https://doi.org/10.5465/amj.2010.52814599 